\title{
THE EFFECT OF SOWING DATE AND NITROGEN FERTILIZER FORM ON GROWTH, YIELD AND YIELD COMPONENTS IN SUNFLOWER
}

\author{
Erdogan OZTURK ${ }^{*}$, Taskın POLAT ${ }^{I}$, Murat SEZEK ${ }^{1}$ \\ Atatürk University, Faculty of Agriculture, Department of Field Crops, Erzurum, TURKEY \\ *Corresponding author: erozturk@atauni.edu.tr
}

Received: 03.03.2017

\begin{abstract}
The purpose of this study was to investigate the effects of sowing date and nitrogen fertilizer forms on the yield and agronomic characteristics of two cultivars of oil sunflower (early, Sirena and late, Teknosol) in Erzurum, Eastern Anatolia of Turkey, in 2013 and 2015. Three sowing dates were established at about 10-day intervals from late-April to early and mid-May (22 April, 2 May and 12 May 2013; and 28 April, 8 May and 18 May 2015). Three nitrogen fertilizer forms ammonium sulfate, ammonium nitrate, and urea were used. The results of this study showed that sunflower seeding from 28 April to 8 May gives more assurance for higher yields. The present results highlighted the practical importance of fertilization with appropriate nitrogen fertilizer forms in seed and oil yield formation in sunflower, and the urea form can be suggested to meet its $\mathbf{N}$ requirements. The yield differences measured for three sowing dates and nitrogen fertilizer forms were primarily related to the changes in head diameter and 1000 seed weights. According to the results of this study, early sunflower cultivars, having the highest yield and agronomic characteristics can be recommended for the similar ecological condition of our study region a short growing season and high altitude.
\end{abstract}

Keywords: Agronomic characteristic, Helianthus annuus L., nitrogenous fertilizer form, sowing date, sunflower, yield,

\section{INTRODUCTION}

Sunflower is one of the most important oilseed plants that has originated from tropical and subtropical regions with wide adaptability and high drought tolerance. High water-holding soils are more suitable for this crop, but it can easily adapted to different soil conditions.

The productivity of sunflower, in terms of growth, yield and yield components, varies widely depending on various environmental factors such as temperature (Kaleem et al., 2011), rainfall distribution (Lawal et al., 2011; Olowe et al., 2013), some agronomic practices, like sowing date (Lawal et al., 2011; Anjum et al., 2012), nitrogen nutrition and sowing of improved varieties and hybrids (Ali et al., 2012). As sunflower is frequently planted after the optimal planting period at different conditions and regions, a new breeding formulation is needed to improve yield under these conditions. Since early spring frost and late summer cool conditions are common, sowing date can play a major role in determining the seed yield and quality in regions with short growing season. Additionally, sowing dates have greatly influenced vegetative and generative growth periods of crops (Ahmed et al., 2015). Sowing date has a significant influence on vegetative traits, together with seed yield and its component (Allam et al., 2003). The late planting is effective in delaying of emergence, flowering, and maturity in cultivars of sunflower. However, in some studies that were conducted at in different ecology and climatic conditions, the sowing date is delayed, growth, seed yield, and quality (oil content) generally tended to decrease (Baghdadi et al., 2014; Ahmed at al., 2015). Oil content for sunflower is determined during the seed filling period which is from the end of flowering to the physiological maturity (Aguirrezabal et al., 2003). It is expressed that the yield and agronomical characteristics of the sunflower were notably higher in the early sown crops whereas the late sown crops showed lower yield and growth (Ali et al., 2004). In addition, the seed yield, head diameter, the ratio of dehulled/hulled seed weight, 1000 seed weight, oil content of seed is positively affected by early sowing of sunflower (Abdou et al., 2011; Ahmed et al., 2015). Results from previous studies also indicated that the seed yield can be reduced by delaying the sowing date (Baghdadi et al., 2014).

In sunflower yield potential is often limited. Nutrients play important role in crop growth and development. Nutrient management is one of the most critical factors affecting seed yield in sunflower. Among the different nutrients, nitrogen is one of the major nutrients that enhances the metabolic processes that based on protein, leads to increases in vegetative, reproductive growth and 
yield of the crop (Koutroubas et al., 2008). Since nitrogen is the most limiting nutrient, it should be received from the soil in significant quantities by plants (Nasim et al., 2012). Nitrogen is readily absorbed by the plants in the forms of nitrate $\left(\mathrm{NO}_{3}\right)$, urea $\left(\mathrm{CO}\left(\mathrm{NH}_{2}\right)_{2}\right)$ and ammonium $\left(\mathrm{NH}_{4}{ }^{+}\right)$. Many studies have confirmed that nitrogen sources and rates on the yield and agronomic characteristics of sunflower were significantly affected (Malik et al., 1999; Yassen et al., 2011). Sunflower was more responses to a higher rate of $\mathrm{N}$ in the form of urea (Hasan and Mukhtar, 2000). However, an increase in plant height, head diameter, 1000 seed weight and seed yield while using ammonium nitrate has been reported by Malik et al. (1999), Osama et al. (2010), Yassen et al. (2011), Soleymani et al. (2013).

Sowing date can show differences even if the cultivars are grown in the same ecological region. Since sunflower cultivars have their own distinctive characteristics and yield potential (Nasim et al., 2012) and therefore have significant differences in terms of yield and quality characteristics. Sunflower production is widely affected by choice of cultivar. Bakht et al. (2006) studied the performance of sunflower cultivars and found a significant difference in yield and its components. It is important to determine appropriate nitrogen fertilizer form to be used and to test its environmental performance in order to increase the productivity of sunflower. The objective of this study was to determine appropriate management practices in production of sunflower during a short growing season and at high altitude conditions by evaluating the effects that sowing date and different sources of nitrogen fertilizer had on seed yield and yield components of two oil type sunflower cultivars.

\section{MATERIALS AND METHODS}

Two separate field experiments were carried out at the Agricultural Experiment and Research Centre, Faculty of Agriculture, Ataturk University in Erzurum (29 $55^{\prime} \mathrm{N}$ and $41^{\circ} 16^{\prime} \mathrm{E}$; $1850 \mathrm{~m}$ above sea level) in 2013 and in 2015. The soil of two experimental sites was a silty loam (fine, mixed, mesic ustorthents) with $\mathrm{pH} 7.6,0.93 \%$ organic matter, $61 \mathrm{~kg} \mathrm{ha}^{-1}$ available $\mathrm{P}$ and $2255 \mathrm{~kg} \mathrm{ha}^{-1}$ available $\mathrm{K}$ in 2013 and $\mathrm{pH} 7.23,1.05 \%$ organic matter, $49 \mathrm{~kg} \mathrm{ha}^{-1}$ available $\mathrm{P}$ and $1949 \mathrm{~kg} \mathrm{ha}^{-1}$ available $\mathrm{K}$ in 2015. Temperature, rainfall, and relative humidity data during the crop-growing period was collected from a weather station that was $1.5 \mathrm{~km}$ from the experimental site, and is presented in Table 1. In both experiments, the previous crop on the plots planted in 2013 and 2015 was wheat (Triticum vulgare L.) and barley (Hordeum vulgare L.). The plot areas were moldboard plowed in the fall and cultivated twice in the spring. In this study, two oil sunflower cultivars, medium early Sirena and late Teknosol, were used.

Table 1. Monthly and growing season precipitation, temperature, and relative humidity in Erzurum in 2013 and 2015.

\begin{tabular}{lccccccccc}
\hline \multirow{2}{*}{ Months } & \multicolumn{3}{c}{ Precipitation $(\mathbf{m m})$} & \multicolumn{3}{c}{ Temperature $\left({ }^{\mathbf{}} \mathbf{C}\right)$} & \multicolumn{3}{c}{ Relative humidity $(\%)$} \\
\cline { 2 - 9 } & $\mathbf{2 0 1 3}$ & $\mathbf{2 0 1 5}$ & Normal $^{\mathbf{a}}$ & $\mathbf{2 0 1 3}$ & $\mathbf{2 0 1 5}$ & Normal & $\mathbf{2 0 1 3}$ & $\mathbf{2 0 1 5}$ & Normal \\
\hline April & 36.3 & 45.0 & 61.4 & 7.2 & 8.1 & 5.2 & 64.4 & 68.7 & 68.0 \\
May & 32.3 & 81.5 & 66.7 & 11.6 & 10.6 & 10.4 & 63.5 & 63.8 & 63.9 \\
June & 25.1 & 28.5 & 41.9 & 15.0 & 17.0 & 14.8 & 57.2 & 50.3 & 59.1 \\
July & 7.8 & 5.8 & 24.5 & 19.4 & 21.2 & 19.1 & 57.2 & 40.3 & 53.7 \\
August & 5.2 & 38.8 & 14.8 & 19.5 & 21.2 & 19.3 & 45.7 & 42.8 & 50.4 \\
September & 11.5 & 3.9 & 20.2 & 13.6 & 18.3 & 13.9 & 49.8 & 39.2 & 52.7 \\
\hline Total or mean & $\mathbf{1 1 8 . 2}$ & $\mathbf{2 0 3 . 5}$ & $\mathbf{2 2 9 . 5}$ & $\mathbf{1 4 . 4}$ & $\mathbf{1 6 . 1}$ & $\mathbf{1 3 . 8}$ & $\mathbf{5 5 . 2}$ & $\mathbf{5 0 . 9}$ & $\mathbf{5 8 . 0}$ \\
\hline
\end{tabular}

Normal refers to the long-term average, a 22-year average.

Two cultivars of sunflowers, "Sirena and Teknosol", and three nitrogen fertilizer forms, "ammonium sulfate, ammonium nitrate and urea", as sub plot were subjected to three sowing dates as main plot between 22 April and 12 May in 2013 and three between 28 April and 18 May in 2015 arranged in split plot layout in randomized complete block design with three replications. Cultivars were sown on three dates each year: 22 April, 2 May, and 12 May 2013; and 28 April, 8 May, and 18 May 2015. First sowing and following sowings were delayed by about 10 days in 2015 when compared with 2013 because of rainfall and excessive wet soil conditions. Hereafter, sowing dates in each year will be referred to as first, second and third. The nitrogen fertilizer being applied were ammonium sulfate $\left(\left(\mathrm{NH}_{4}\right)_{2} \mathrm{SO}_{4}\right)$, ammonium nitrate $\left(\mathrm{NH}_{4} \mathrm{NO}\right)$ and urea $\left(\mathrm{CO}\left(\mathrm{NH}_{2}\right)_{2}\right)$. The nitrogen and phosphorus was incorporated into the seedbed before sowing occurred in both years. All the experimental plots received nitrogen at the rate of $\mathrm{kg} 100 \mathrm{~kg} \mathrm{ha}^{-1}$, phosphorus at the rate of $80 \mathrm{~kg} \mathrm{P}_{2} \mathrm{O}_{5} /$ ha was triple superphosphate in individual years. Potassium was not included in fertilization program because the soil had a very high level of $\mathrm{K}$. The plots were $2.8 \mathrm{~m}$ wide and $6 \mathrm{~m}$ long and consisted of four rows. The sunflower cultivars were sown in rows that were $70 \mathrm{~cm}$ apart, and $35 \mathrm{~cm}$ within the rows. Three seeds were sown in each hill, and then the plots were hand-thinned to one plant per hill when the plants were at the four to six-leaf stage. Weeds were controlled both mechanically and by hand using hoe. All plots were furrow irrigated regularly to avoid drought stress. Each irrigation brought the soil moisture back to near field capacity. Water was applied uniformly to all plots. The sunflower plants were hand-harvested at the physiological maturation stage when the back of the sunflower head has turned from green to yellow and the bracts are turning brown. The dates were as follows 7-23 September in 2013 
and 12-30 September in 2015. At the harvest, ten plants (total plot area $(2.8 \times 6) 16 \mathrm{~m}^{2}$ and harvest area $(0.70 \mathrm{x}$ $0.35 \times 10) 2.45 \mathrm{~m}^{2}$ ) were selected from each plot in order to determine plant height, head diameter, the ratio of dehulled/hulled seed weight and 1000-seed weight. At maturity, head samples were harvested to check for yield from the two center rows of each plot, which had to be dried and threshed mechanically. Seed yield was adjusted to a $10.0 \%$ moisture basis. Seed oil concentration was determined by the Soxhlet apparatus.

All the data was analyzed using the SPSS package ((SPSS, Version 20.0, SPSS Inc, Chicago, IL, USA). Results for each year were analyzed separately because sowing dates differed between the two seasons and were presented by individual year. For statistical analyses, sowing date, cultivar, and nitrogen fertilizer form effects were considered fixed. When the $F$-test indicated statistical significance at the $\mathrm{P}=0.05$ level, the protected least significant difference (Protected DUNCAN) was used to separate the means (Steel and Torrie, 1980).

\section{RESULTS AND DISCUSSION}

The monthly rainfall, average temperatures, and relative humidity data for 2013 and 2015 is presented in Table 1. Air temperatures during the two growing seasons were close to the long-term mean. April to September temperature, which averages $13.8{ }^{\circ} \mathrm{C}$ were slightly above normal in 2013 and 2015. There was considerable variability in rainfall amounts and distribution from year to year. The 2013 and 2015 rainfall was below the longterm average. The average rainfall for 2015 (203.5 $\mathrm{mm}$ ) was higher than that observed $(118.2 \mathrm{~mm})$ in 2013 . The mean for the 2013 relative humidity was similar to longterm mean, whereas relative humidity in 2015 was below normal (Table 1).

According to the results obtained from this study, the applied sowing dates affected head diameter and ratio of dehulled/hulled seed weight $(\mathrm{p}<0.01)$, oil content, seed and oil yield $(\mathrm{p}<0.05)$ except plant height and thousand seed weight in 2013. In addition, the sowing dates showed significant $(\mathrm{p}<0.05)$ effects on plant height, head diameter, thousand seed weight, oil content, seed and oil yield except for ratio of dehulled/hulled seed weight in the second year of study. Nitrogen fertilizer forms have a significant $(\mathrm{p}<0.05)$ effects on 1000 seed weight and the ratio of dehulled/hulled seed weight in the 2013 year, whereas nitrogen fertilizer forms on all trait were significant $(\mathrm{P}<0.01)$ in the second year of study. On the other hand, cultivars effects on yield and agronomic traits were significant $(\mathrm{p}<0.01)$ in 2013 and 2015 growing seasons, except head diameter at two years (Table 2 and 3).

Table 2. Influence of sowing date, cultivar, and nitrogen forms on yield and some agronomic characters of oilseed sunflower grown in 2013.

\begin{tabular}{|c|c|c|c|c|c|c|c|c|}
\hline Treatments & & $\begin{array}{c}\text { Plant } \\
\text { height } \\
\text { (cm) }\end{array}$ & $\begin{array}{c}\text { Head } \\
\text { diameter } \\
(\mathbf{c m})\end{array}$ & $\begin{array}{l}1000 \text { Seed } \\
\text { Weight } \\
\text { (g) }\end{array}$ & $\begin{array}{l}\text { The ratio of } \\
\text { dehulled/ } \\
\text { hulled seed } \\
\text { weight } \\
(\%)\end{array}$ & $\begin{array}{c}\text { Seed } \\
\text { yield } \\
\left(\mathrm{kg} \mathrm{ha}^{-1}\right)\end{array}$ & $\begin{array}{c}\text { Oil } \\
\text { content } \\
(\%)\end{array}$ & $\begin{array}{c}\text { Oil } \\
\text { yield } \\
\left(\mathbf{k g ~ h a}^{-1}\right)\end{array}$ \\
\hline \multicolumn{9}{|c|}{ Sowing date $(D)$} \\
\hline April 22 & & 146.0 & $20.0 \mathrm{a}$ & 64.5 & $71.8 \mathrm{~b}$ & $2731 \mathrm{a}$ & $47.4 \mathrm{a}$ & $1310 \mathrm{a}$ \\
\hline May 2 & & 144.6 & $18.8 \mathrm{~b}$ & 64.4 & $72.8 \mathrm{a}$ & $2468 \mathrm{~b}$ & $43.1 \mathrm{~b}$ & $1108 \mathrm{~b}$ \\
\hline May 12 & & 144.9 & $19.0 \mathrm{~b}$ & 63.9 & $72.2 \mathrm{a}$ & $2459 \mathrm{~b}$ & $42.6 \mathrm{~b}$ & $1057 \mathrm{~b}$ \\
\hline \multicolumn{9}{|c|}{ Nitrogen form (NF) } \\
\hline Ammonium sulfate & & 142.5 & 19.4 & $64.2 \mathrm{ab}$ & $73.1 \mathrm{a}$ & 2527 & 44.9 & 1153 \\
\hline Ammonium nitrate & & 146.5 & 19.3 & $65.6 \mathrm{a}$ & $71.7 \mathrm{~b}$ & 2614 & 43.1 & 1126 \\
\hline Urea & & 146.3 & 19.1 & $62.9 \mathrm{~b}$ & $72.0 \mathrm{~b}$ & 2518 & 45.1 & 1197 \\
\hline \multicolumn{9}{|c|}{ Cultivar $(C)$} \\
\hline Sirena & & $141.6 \mathrm{~b}$ & 19.2 & $68.1 \mathrm{a}$ & $75.1 \mathrm{a}$ & $2873 \mathrm{a}$ & $48.1 \mathrm{a}$ & $1414 \mathrm{a}$ \\
\hline Teknosol & & $148.6 \mathrm{a}$ & 19.3 & $60.5 \mathrm{~b}$ & $69.4 \mathrm{~b}$ & $2233 b$ & $40.6 \mathrm{~b}$ & $903 \mathrm{~b}$ \\
\hline Mean & & 145.2 & 19.3 & 64.3 & 72.3 & 2553 & 44.4 & 1159 \\
\hline \multicolumn{9}{|c|}{ Analysis of Variance $\quad d f$} \\
\hline$\overline{\mathbf{D}}$ & 2 & ns & $* *$ & ns & ns & $*$ & * & * \\
\hline Error $_{1}$ & 4 & & & & & & & \\
\hline NF & 2 & ns & ns & $*$ & $*$ & ns & ns & ns \\
\hline $\mathbf{C}$ & 1 & $* *$ & ns & $* *$ & $* *$ & $* *$ & $* *$ & $* *$ \\
\hline D x C & 2 & ns & ns & ns & ns & ns & ns & ns \\
\hline $\mathrm{D} \times \mathrm{NF}$ & 4 & ns & ns & ns & ns & ns & ns & ns \\
\hline NF $\times$ C & 2 & ns & ns & $*$ & $*$ & ns & ns & ns \\
\hline $\mathrm{D} \times \mathrm{NF} \times \mathrm{C}$ & 4 & ns & ns & ns & ns & ns & ns & ns \\
\hline Error2 & 30 & & & & & & & \\
\hline
\end{tabular}


Table 3. Influence of sowing date, nitrogen forms and cultivar on yield and some agronomic characters of oilseed sunflower grown in 2015 .

\begin{tabular}{|c|c|c|c|c|c|c|c|}
\hline Treatments & $\begin{array}{c}\text { Plant } \\
\text { height } \\
(\mathrm{cm})\end{array}$ & $\begin{array}{c}\text { Head } \\
\text { diameter } \\
(\mathrm{cm})\end{array}$ & $\begin{array}{l}1000 \text { Seed } \\
\text { Weight } \\
\text { (g) }\end{array}$ & $\begin{array}{l}\text { The ratio of } \\
\text { dehulled/ } \\
\text { hulled seed } \\
\text { weight } \\
(\%)\end{array}$ & $\begin{array}{c}\text { Seed } \\
\text { yield } \\
\left(\mathrm{kg} \mathrm{ha}^{-1}\right)\end{array}$ & $\begin{array}{c}\text { Oil } \\
\text { content } \\
(\%)\end{array}$ & $\begin{array}{c}\text { Oil } \\
\text { yield } \\
\left(\mathbf{k g ~ h a}^{-1}\right)\end{array}$ \\
\hline \multicolumn{8}{|c|}{ Sowing date $(D)$} \\
\hline April 28 & $184.8 \mathrm{a}$ & $21.1 \mathrm{a}$ & $68.4 \mathrm{a}$ & 68.5 & $3033 \mathrm{a}$ & $38.3 \mathrm{a}$ & $1179 \mathrm{a}$ \\
\hline May 8 & $181.2 \mathrm{ab}$ & $21.0 \mathrm{a}$ & $66.2 \mathrm{ab}$ & 69.3 & $3004 \mathrm{a}$ & $37.1 \mathrm{~b}$ & $1112 \mathrm{ab}$ \\
\hline May 18 & $177.9 \mathrm{~b}$ & $20.1 \mathrm{~b}$ & $64.3 \mathrm{~b}$ & 69.1 & $2887 \mathrm{~b}$ & $36.9 \mathrm{~b}$ & $1085 \mathrm{~b}$ \\
\hline \multicolumn{8}{|c|}{ Nitrogen form $(N F)$} \\
\hline Ammonium sulfate & $183.6 \mathrm{a}$ & $21.2 \mathrm{a}$ & $64.9 \mathrm{~b}$ & $70.2 \mathrm{a}$ & $2886 \mathrm{~b}$ & $37.3 \mathrm{~b}$ & $1084 \mathrm{~b}$ \\
\hline Ammonium nitrate & $184.6 \mathrm{a}$ & $20.2 \mathrm{~b}$ & $68.1 \mathrm{a}$ & $67.0 \mathrm{~b}$ & $2803 \mathrm{~b}$ & $38.2 \mathrm{a}$ & $1094 \mathrm{~b}$ \\
\hline Urea & $175.7 \mathrm{~b}$ & $20.1 \mathrm{~b}$ & $65.9 \mathrm{~b}$ & $69.7 \mathrm{a}$ & $3234 \mathrm{a}$ & $36.8 \mathrm{a}$ & $1214 \mathrm{a}$ \\
\hline \multicolumn{8}{|c|}{ Cultivar (C) } \\
\hline Sirena & $172.7 \mathrm{~b}$ & 20.4 & $69.9 \mathrm{a}$ & $71.3 \mathrm{a}$ & $3330 \mathrm{a}$ & $42.8 \mathrm{a}$ & $1424 \mathrm{a}$ \\
\hline Teknosol & $191.9 \mathrm{a}$ & 21.0 & $62.6 \mathrm{~b}$ & $66.6 \mathrm{~b}$ & $2618 \mathrm{~b}$ & $32.1 \mathrm{~b}$ & $838 \mathrm{~b}$ \\
\hline Mean & 181.3 & 20.7 & 66.3 & 65.5 & 2974 & 37.4 & 1131 \\
\hline \multicolumn{8}{|c|}{ Analysis of Variance $\quad d f$} \\
\hline $\mathbf{D}$ & 2 & $*$ & * & $\overline{\mathrm{ns}}$ & $*$ & * & $*$ \\
\hline Error $_{1}$ & 4 & & & & & & \\
\hline NF & $* *$ & $* *$ & $* *$ & $* *$ & $* *$ & $* *$ & $* *$ \\
\hline $\mathbf{C}$ & $* *$ & ns & $* *$ & $* *$ & $* *$ & $* *$ & $* *$ \\
\hline D $\times$ C & ns & ns & ns & ns & ns & $* *$ & $* *$ \\
\hline D $x$ NF & ns & ns & ns & ns & $* *$ & ns & $* *$ \\
\hline NF $\times$ C & $* *$ & $* *$ & $*$ & ns & $* *$ & ns & $* *$ \\
\hline $\mathrm{D} \times \mathrm{NF} \times \mathrm{C}$ & 4 & ns & ns & ns & $* *$ & ns & $* *$ \\
\hline Error $_{2}$ & 30 & & & & & & \\
\hline
\end{tabular}

*, ** significant at the 0.05 and 0.01 level, respectively. For each main effect, values within columns followed by the same letter are not significant., NS, nonsignificant.

No sowing date $\mathrm{x}$ cultivar $\mathrm{x}$ nitrogen fertilizer form interaction was observed for yield and agronomic traits (Tables 2 and 3), except seed and oil yield in 2015 growing season. Sowing date $\mathrm{x}$ cultivar (except oil content and oil yield $(\mathrm{p}<0.01)$ in 2015$)$, sowing date $x$ nitrogen fertilizer form (except seed and oil yield $(p<0.01)$ in 2015$)$ and cultivar $\mathrm{x}$ nitrogen fertilizer form (except 1000 seed weight and the ratio of dehulled/hulled seed weight in $2013(\mathrm{p}<0.05)$ and 1000 seed weight $(\mathrm{p}<0.05)$, plant height, head diameter, seed and oil yield $(p<0.01)$ in 2015$)$ interaction was usually insignificant and consistent between years for yield and other agronomic traits.

\section{Plant Height}

Averaged over all treatments the plants grown in 2013 had $36.1 \mathrm{~cm}$ shorter plant height than that in 2015, probably due to varying weather (rainfall amounts) conditions. The tallest plant height was observed in the second year when the highest amount of rainfall was recorded during the growing season (Table 1). This was apparently associated with the cooler weather conditions prevailing during the early growth stage and flowering, particularly at the first two sowing dates. In contrast, to the second year of study delayed sowing caused consistent reduction in plant height. Differences between cultivars were observed for plant height in both years (Tables 2 and 3). Teknosol (148.6 and $191.9 \mathrm{~cm})$ produced significantly taller plants than Sirena $(141.6$ and $172.7 \mathrm{~cm})$. This difference between cultivars in plant height seems to be under genetic control. Similarly, Ali et al. (2004) concluded that sunflower cultivars significantly affect in plant height and this difference may be due to varietal behavior. The observations were also supported by Baghdadi et al. (2014) and Ahmed et al. (2015), who reported that the plant heights of sunflower increased with the first sowings. Average plant heights of cultivars significantly decreased when there was a delay in the sowing date for the first and second year of the study. The highest plant height was determined at the first sowing dates in 2013 and 2015 years, 146.0 and $184.8 \mathrm{~cm}$, respectively. The results suggest that the plant height varied according to nitrogen forms. Plant height was longer in the plot treated with ammonium nitrate in 2013 and 2015 years $(146.5$ and $184.6 \mathrm{~cm})$ (Table 2 and 3), as it has been previously reported (Abdelgadir et al., 2010; Yassen et al., 2011).

\section{Head Diameter}

The head diameter is one of the components that effects yield. Head diameter of a sunflower was significantly affected by ecological factors such as temperature, soil moisture and productivity and agricultural applications such as sowing time. The head diameter of the sunflower cultivars in 2013 and 2015 growing seasons were 19.3 and $20.7 \mathrm{~cm}$ on average respectively. The mean of the 2013 head diameter was similar to the one in the second growing season. In addition to the inadequate precipitation in the first year of 
study, the efficiency of precipitation in the second year was reflected in at the size of the head diameter There was significantly decrease in head diameter from April 22nd to May 12th in 2013 and from April 28th to May 18th in 2015. The maximum head diameter was determined at the first sowing dates in both years $(20.0$ and $21.2 \mathrm{~cm})$. The significant difference in the aforementioned vegetative parameters could be explained by the availability of adequate moisture, which enables roots to absorb enough nutrients for plant growth (Lawal et al., 2011). The head diameter was less in ammonium nitrate $(19.3$ and $20.2 \mathrm{~cm})$ and urea $(19.1$ and $20.2 \mathrm{~cm}$ ) than in ammonium sulphate (19.4 and $21.2 \mathrm{~cm})$ in 2013 and 2015 years, respectively, but the effect of nitrogen fertilizer forms on the head diameter was insignificant in 2013. As it can be seen in Table 2 and 3, the head diameter obtained from the two cultivars were alike in both years. The values recorded were $19.2 \mathrm{~cm}$ and $20.4 \mathrm{~cm}$ for Sirena and $19.3 \mathrm{~cm}$ and $21.0 \mathrm{~cm}$ for Teknosol, in first and second years of study, respectively. Cultivar Teknosol had a higher head diameter than Sirena in 2013 and 2015 years (Table 2 and 3).

\section{Seed Weight}

Thousand seed weight is another yield component in sunflower. Thousand seed weight differs based on various growing seasons and conditions. In 2015 when rainfall was high, the 1000 seed weight $(66.3 \mathrm{~g}$ and $64.3 \mathrm{~g})$ was higher than in 2013, (Table 2 and 3). Tables 2 and 3 revealed that delaying sowing resulted in a decrease in 1000 seed weight in two years. The highest 1000 seed weight was obtained from first (64.5 and $64.4 \mathrm{~g}$ ) and second sowing dates $(68.4$ and $66.2 \mathrm{~g}$ ) at both the first year and second year. The reduction in the 1000-seed weights for the late sown sunflower can be attributed to an increase in temperature (Hocking and Stapper, 2001) and a decrease in the magnitude of the leaf area, which is considered a factor of high importance in terms of seed growth. Allam et al. (2003) reported that sowing date influenced oil content of sunflower. Applications of nitrogen fertilizer had a significant effect on seed weight. The highest 1000 seed weight $(65.6 \mathrm{~g}$ and $68.1 \mathrm{~g})$ was determined for ammonium nitrate form of nitrogen used in 2013 and in 2015. Similarly, Soleymani et al. (2013) reported that 1000 seed weight of sunflower was consistently influenced by nitrogen and that it increased even higher with the use of ammonium nitrate form (Table 2 and 3), as reported by Yassen et al. (2011). On the other hand, the highest thousand seed weight was reported for ammonium sulphate by Malik et al. (1999), Toosi and Azizi (2014). Apparently, a similar trend was seen where an increase of thousand seed weight occurred during the first and second year for two cultivars. Sirena had 1000 seed weight mean such as 68.1 in the first year and then it increased to $69 \mathrm{~g}$ in the second year. Similarly, Teknosol had $60.5 \mathrm{~g}$ in the first year and $62.6 \mathrm{~g}$ in the second year. However, thousand seed weight of Sirena cultivar was higher than that of Teknosol in both years.

\section{The Ratio of Dehulled/Hulled Seed Weight}

Table 2 shows the ratio of dehulled/hulled seed weights for sunflower cultivars grown in the 2013 and 2015 growing seasons. In general, sunflower genotypes tended to produce higher ratio of dehulled/hulled seed weight in $2013(72.3 \%)$ than that of 2015 (65.5\%). In 2013 and 2015 the lowest ratio of dehulled/hulled seed weight was found at the first sowing ( 22 and 28 April). As mentioned earlier, this might be a result of cooler conditions prevailed during the first sowing season. The highest ratio of dehulled/hulled seed weight (72.8 and $69.3 \%$ ) was obtained from the second sowing dates, and at the later sowing dates a reduction occurred in both years. The ammonium sulfate form and Sirena cultivar dates were shown to give better ratio of dehulled/hulled than other fertilizer forms and sunflower cultivar in 2013 and in 2015 (73.1 and 70.2\%; 71.3 and $75.1 \%$ respectively). Shorter growing season in the field for specific cultivar resulted in higher yield components such as ratio of dehulled/hulled seed weight.

\section{Seed Yield}

Seed yield is considerably affected by the ecological factors and agricultural techniques as well as the genotype. The productivity of sunflower is largely determined by the prevailing weather conditions throughout its life cycle and the imposed cultural practices (Kaleem et al., 2011). Agricultural applications such as sowing date and fertilizer application and some environmental factors (temperature and rainfall) are major factors which affect plant growth and development. Averaged over the cultivars, sowing dates and nitrogen fertilizer forms, yields $\left(2974 \mathrm{~kg} \mathrm{ha}^{-1}\right)$ from the second year were superior to those $\left(2553 \mathrm{~kg} \mathrm{ha}^{-1}\right)$ obtained in the first year (Table 2 and 3). The high sunflower yields in 2015 may have resulted in higher $\mathrm{N}$ mineralization due to increased rainfall. In general, the low yields in this study were probably due to the short growing season and high altitude. A delay in sowing, generally tended to decrease seed yield in the two years. The highest seed yield obtained at April 22 and 28th (2731 and $3033 \mathrm{~kg} \mathrm{ha}^{-1}$ ), and the lowest yield was obtained on May 12 and 18th (2459 and $2887 \mathrm{~kg} \mathrm{ha}^{-1}$ ) in two years. This also accounts for the positive response in agronomic characteristics that are associated with yields such as head diameter and 1000 seed weight. The yield reductions in later sowings could be explained by lower head diameter and 1000 seed weight. On the other hand, the highest yield of first sowing could be explained by using of early spring rains (Killi and Altunbay, 2005). Similarly, Baghdadi et al. (2014) concluded that seed yield generally decreased with delayed sowing which might be attributed to the decrease in some yield components. According to, Martre (2009) and Bajehbaj (2009), longer growing times in the field for some cultivars resulted in higher yield and yield components such as head diameter, 1000 seed weight, and seed yield. That is, those planted early had their seed filling stage with adequate moisture compared with those 
planted late; as a result, they had good seed settings. This increase in seed yield with first sowing has been verified in early field studies (Soriano et al., 2004; Ali et al., 2004; Lawal, 2011; Soleymani at al., 2013; Baghdadi et al., 2014; Ahmed et al., 2015). Our results agreed with the findings of previous researches. Although the seed yield of this study showed differences from other studies due to usage of the different cultivars at the different ecological condition.

The results showed that effect of nitrogen fertilizer forms on seed yield was significant in 2015, but there was no significant effect in the 2013 growing season, probably due to differing environmental conditions (Table 2 and 3 ). In 2013, seed yield was higher in plots treated with ammonium nitrate $\left(2614 \mathrm{~kg} \mathrm{ha}^{-1}\right)$ than that of ammonium sulphate $\left(2527 \mathrm{~kg} \mathrm{ha}^{-1}\right)$ and urea $\left(2518 \mathrm{~kg} \mathrm{ha}^{-1}\right)$ plots. However, a similar trend was nor observed in the 2015 growing season. The urea (3234 $\left.\mathrm{kg} \mathrm{ha}^{-1}\right)$ showed higher yield, followed by ammonium sulphate $\left(2886 \mathrm{~kg} \mathrm{ha}^{-1}\right)$ and ammonium nitrate $\left(2803 \mathrm{~kg} \mathrm{ha}^{-1}\right)$, but the differences between ammonium sulphate and ammonium nitrate fertilizer types were not statistical significant (Table 2). In the first year, ammonium nitrate form of nitrogen caused an increase in seed yield of sunflower (Table 2), as it has been previously reported (Abdelgadir et al., 2010; Yassen et al., 2011). The same results in the 2015 growing season were reported for different environments (Osama et al., 2010). Hasan, Mukhtar (2000) found that seed yield increased with the use of urea and ammonium sulphate.
Contrary to these reports Toosi and Azizi (2014) reported that Ammonium sulphate produced the highest seed yield.

It is known that the most important factors affecting in yield traits of sunflower is the genotype. As can be seen from Tables 2 and 3, there were statistical significant differences between two sunflower cultivars for seed yield in both years. Sirena tended to be higher in seed yield (2873 and $3330 \mathrm{~kg} \mathrm{ha}^{-1}$ ) than Teknosol (2233 and $2618 \mathrm{~kg}$ $\mathrm{ha}^{-1}$ ) which is a genotype dependent characteristics. Various studies (Ozer et al., 2003; Karaaslan et al., 2007; Ali et al., 2012; Nasim et al., 2012; Hussain et al., 2015) suggested that the cultivars showed wide differences in their agronomic characteristics and seed yield.

A differential response occurred between cultivars while changing the form of $\mathrm{N}$ fertilizer in 2015 . A cultivar $x$ nitrogen fertilizer form interaction (Tables 2) in the variance analysis was caused by changes in the magnitude of response between cultivars since nitrogen fertilizer form rankings for seed and oil yield (Fig 1 and 2) were not identical. In addition, in the 2015 season, the two sunflower cultivars differed in their response to sowing dates. Consequently, the significant cultivar $\mathrm{x}$ sowing date interaction was observed for oil content and yield (Table 2; Fig 2). Similarly, in the same year, nitrogen fertilizer forms differed in their response to sowing dates for seed and oil yield of sunflower. Therefore, the significant nitrogen fertilizer form $\mathrm{x}$ sowing date interaction was observed for seed and oil yield (Fig. 1 and 2).

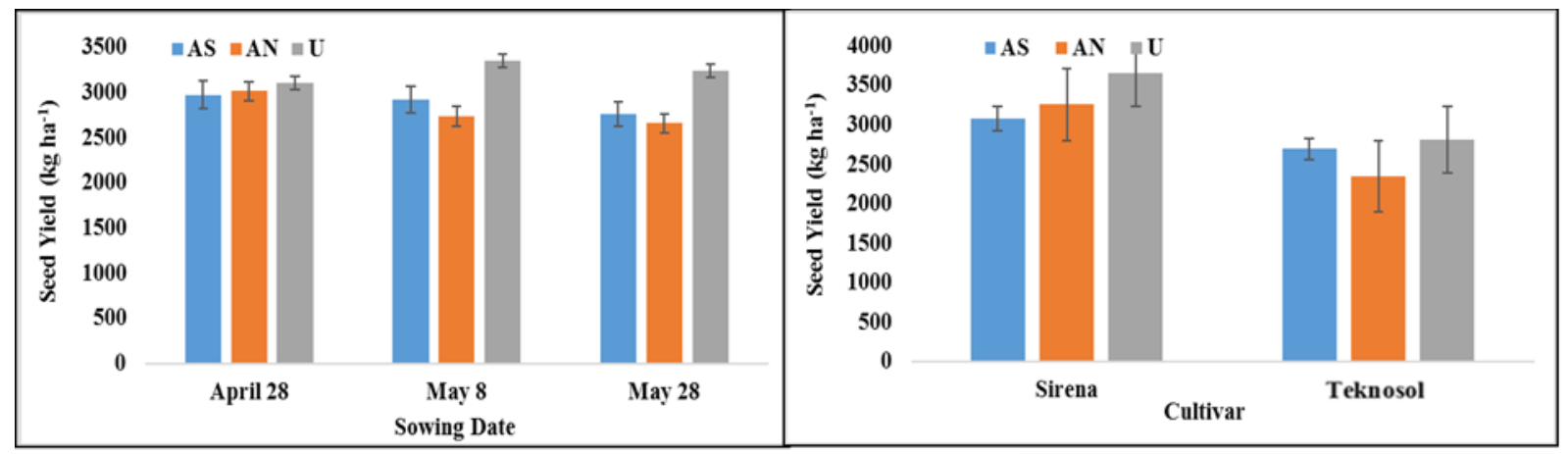

(a)

(b)

Figure 1. Influence of sowing date and nitrogen fertilizer form (a), cultivar and nitrogen fertilizer form (b) on seed yield of sunflower in 2015 


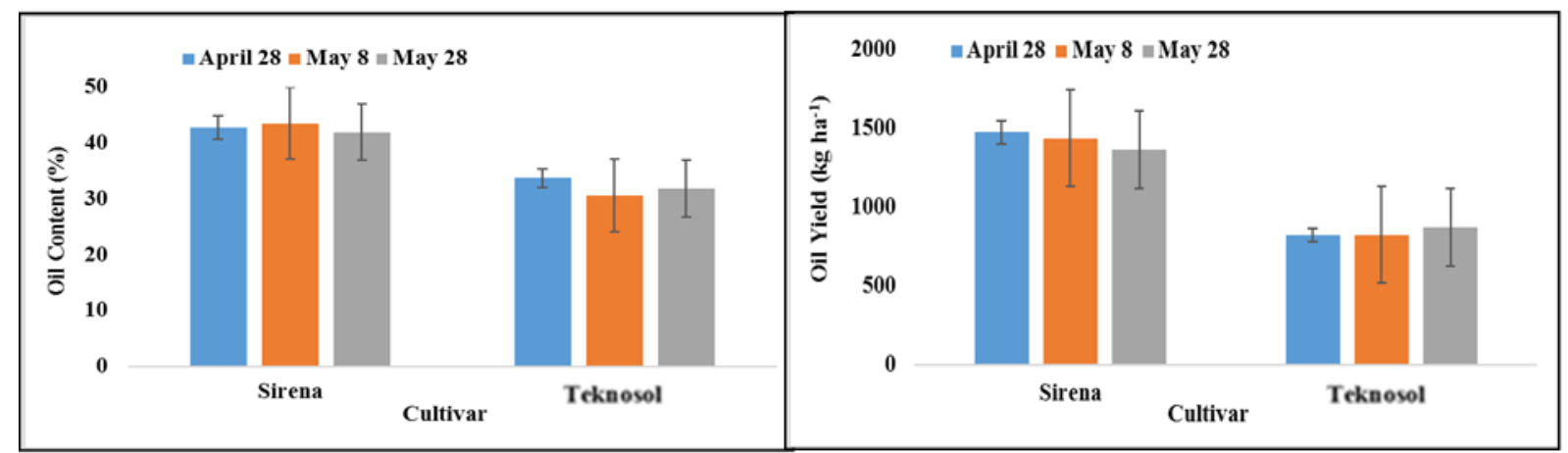

(a)

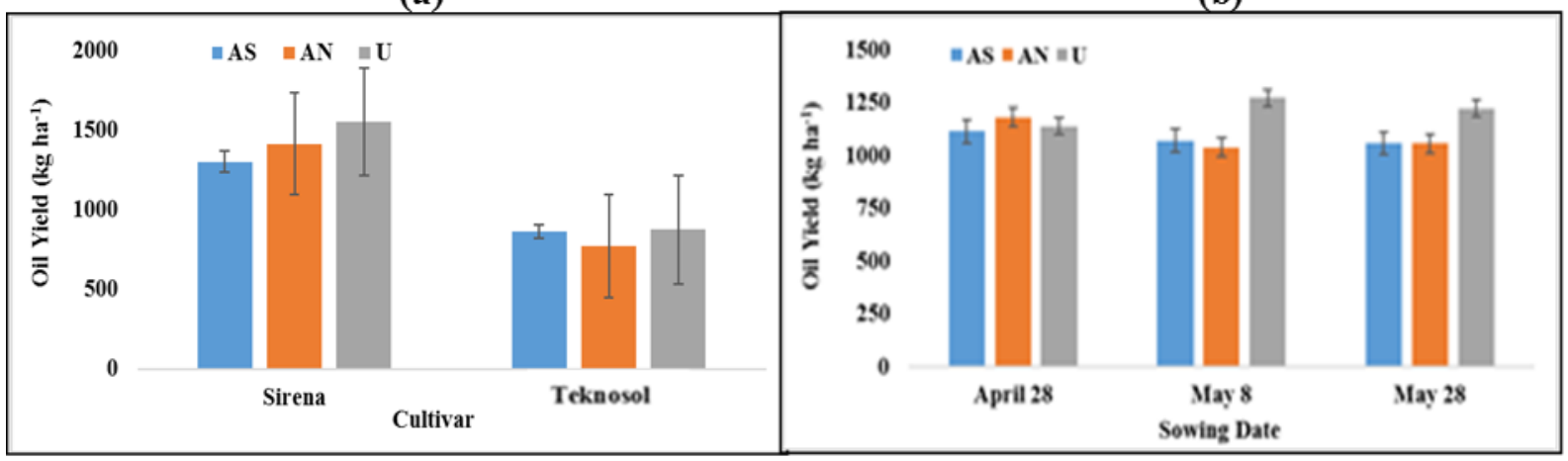

(c)

(d)

Figure 2. Influence of sowing date and nitrogen fertilizer form (a) oil content of sunflower and sowing date and cultivar (b), nitrogen fertilizer form and cultivar (c) sowing date and nitrogen fertilizer form (d) oil yield of sunflower in 2015.

\section{Oil Content}

The oil content of sunflower seed is a quantitative characteristic which is affected by environmental conditions significantly as well as genotype. Seed oil content varied during the study years. The average oil content for $2013(44.4 \%)$ was higher than that observed (37.4\%) in 2015 (Tables 2 and 3). Decrease in oil content of the second year might be related to wetter weather conditions. High temperature during the development of the seed (in 2015) may be associated with a reduction in oil content (Table 1). In addition the decrease in seed oil contents might have been due to more water uptake, resulting in dilution of oil. At both years, oil content generally was reduced as sowing was delayed. The highest oil content was obtained from the first sowing dates (47.4 and $38.3 \%$ ) in 2013 and in 2015, respectively. It is likely that increased temperature and water stress during the seed filling could be a major cause for reduction in oil content due to late sowing (Hocking and Stapper, 2001). These results are in agreement with those reported by Pritchard et al. (2000), who reported that high oil contents were correlated with cooler spring temperatures. Comparing ammonium sulphate, ammonium nitrate and urea fertilizers the means indicated that oil content increased with ammonium nitrate in 2015 compared with 2013. The oil content values in the 2013 year of the study were very close to each other and there were no significant differences among the nitrogen fertilizer forms for oil content (Tables 2 and 3). In 2013 the increased oil concentration of seed caused by the urea form of nitrogen was not surprising since similar effects have been reported by the Osama et al. (2010). On the other hand, Yassen et al. (2011) also showed that the oil content increased with ammonium nitrate form of nitrogen Krisztina et al. (2002) showed that $\mathrm{NH}_{4}$ applied plants (wheat, maize, and sunflower) were more sensitive to salinity than $\mathrm{NO}_{3}$ applied plants. The biomass production of ammonium applied was lower than that of nitrate applied plants. Sunflower cultivars were significantly varied form oil content. In 2013, cultivars produced higher oil contents (39.78\%) as compared to in 2015. Sirena cultivar had the highest oil (48.1 and 42.8\%) as compared to Teknosol (40.6 and 32.1\%) in first and second year of the study. The sunflower seed quality is a joint function of the genetic, environmental conditions and agronomical applications (Petcu et al., 2010; Olowe et al., 2013). Allam et al. (2003) and Ada and Tamkoc (2015) reported that planting date has also influenced oil content of sunflower cultivars.

\section{Oil Yield}

The oil yield is a result of the seed yield and oil content. The oil yield obtained in this study was substantially altered by sowing date, nitrogen fertilizer form, and cultivar except for nitrogen fertilizer form in 2013. Both years (1159 and $\left.1131 \mathrm{~kg} / \mathrm{ha}^{-1}\right)$ were similar in respect to seed oil yield (Tables 2 and 3). However, in 2013 in the oil yield was higher than that of in 2015. The difference between means for oil yield in two years of the study might be associated with a reduction in oil content and an increase in total seed yield (Table 2 and 3). According to sowing date, oil yield varied in the study years. In both years, oil yield generally reduced as sowing 
was delayed. The highest oil yield (1310 and $1179 \mathrm{~kg} / \mathrm{ha}$ ) obtained when sunflower was sawn at the end of April (in first sowing) rather than toward the early (second sowing) or at middle (third sowing) of May in two years. Various studies showed that reduced oil yield in late sowings was primarily related to a significantly lower oil content and reduced seed yield (De la Vega et al., 2007; Lawal et al., 2011). These findings supported our findings. Irrespective of cultivars and sowing dates, in urea form of the nitrogen fertilizers, increased total oil yields in except 2013 (1197 $\mathrm{kg} / \mathrm{ha})$ and in $2015(1214 \mathrm{~kg} / \mathrm{ha})$ years due to the increase in seed yield. The oil yield obtained by the applying nitrogen fertilizers was similar in the first year of study (Table 2). Oil yields of two cultivars were completely different (Tables 2 and 3). Similar to seed yield and oil content, the oil yield of Sirena cultivar (1414 and 14244 $\mathrm{kg} / \mathrm{ha}$ ) was more than Teknosol (903 and $838 \mathrm{~kg} / \mathrm{ha}$ ) in 2013 and in 2015. It could be generalized that at all applications with higher oil yield from the unit area with lower oil content had a higher seed yield.

\section{CONCLUSIONS}

Sunflower is sensitive to sowing date and nitrogen fertilization, so sowing date and nitrogen fertilizer forms were studied to maximize yield and quality of sunflower. The results of the study were in agreement with other research, indicating the effects of sowing date and nitrogen fertilizer forms on yield and agronomic characteristics. Yield and yield components of two sunflowers generally tended to decrease with delayed sowing in two years. Therefore it is important to make right decision for sowing date. The effect of $\mathrm{N}$ fertilizer forms on seed yield and yield components of sunflower was found to be significant in 2015. While, the effect of fertilizer forms was not effective in 2013, except thousand seed weight. The two sunflower cultivars had significant differences for nearly all characteristics measured.

Sunflower's yield performance in regard to sowing date was distinctive for each year of this study and might be largely attributed to seasonal weather differences. Yield and yield components of sunflower declined when sowing time was delayed by 10 or 20 days. In general, sowing sunflower from 28 April to 8 May was optimal for Erzurum. Sowings after this time usually resulted in substantial seed yield reductions. When different forms of fertilizer were applied, fertilizer characteristics, ecological and climatical differences should be consider of the results of this study highlighted the practical importance of appropriate nitrogen fertilizer forms of fertilization in seed and oil yield formation of sunflower and suggested that the form of urea will be the best for the crop to meet its $\mathrm{N}$ requirements. In general, early sunflower cultivars having the highest yield and agronomic characteristics should be recommend for the region with the short growing season and high altitude. As a result, a significant relationship between sowing times, nitrogen fertilizer forms and each of sunflower yield components and seed yield indicated that yield characteristics depend upon sowing times and nitrogen fertilizer forms.

\section{LITERATURE CITED}

Abdou, S.M.M., K.M. Abd El-Latif, R.M.F. Farrag, K.M.R. Yousef. 2011. The response of Sunflower Yield and Water Relations to Sowing Dates and İrrigation Scheduling Under Middle Egypt Condition. Adv.Appl. Sci. Res., 2 (3):141-151.

Abdelgadir, E.M., E.M. Fadul, E.A. Fageer, E. A.Ali. 2010. Response of Wheat to Nitrogen Fertilizer at Reclaimed High Terrace Salt-affected Soils in Sudan. Journal of Agriculture and Social Sciences, 6 (3): 43-47.

Ada, R. and A. Tamkoç. 2015. Determination of Some Agricultural Characteristics in the Sunflower Genotypes Developed as Second Crop, Selcuk Journal of Agriculture and Food Sciences, 29 (2): 44-50.

Ahmed, B., M. Sultana, J. Zaman, S.K. Paul, M.M. Rahman, M.R Islam, F. Majumdar. 2015. Effect of Sowing Dates on The Yield of Sunflower. Bangladesh Agron. J., 18 (1): 1-5.

Aguirrezabal, L.A.N., Y. Lavaud, G.A.A. Dosio, N.A. Izquierdo, F.H. Andrade, L. Gonzalez. 2003. Intercepted Solar Radiation During seed Filling Determines Sunflower Weight Per Seed and Oil Concentration. Crop Sci., 43: 152-61

Allam, A.Y., G.R. El-Nagar, A.H. Galal. 2003. The response of Two Sunflower Hybrids to Planting Dates and Densities. Acta Agron. Hung., 51 (1): 25-35.

Ali, H., S.A. Randhawa, M. Yousaf. 2004. Quantitative and Qualitative Traits of Sunflower (Helianthus annuus L.) as Influenced by Planting Dates and Nitrogen Application. International Journal of Agriculture and Biology, 6 (2): 410412 .

Ali, A., A. Ahmad, T. Khaliq, J. Akhatar. 2012. Planting Density and Nitrogen Rates Optimization for Growth and Yield of Sunflower (Helianthus annuus L.) Hybrids. The Journal of Animal and Plant Sciences, 22: 1070-1075.

Anjum, A.S., S. Muhammad, M. Imran, M. Arshadullah. 2012. The Performance of Early and Late Sown Sunflower Hybrids under Organic Farming System in Rainfed Area. Science Technology and Development, 31: 26-28.

Baghdadi, A., A.H. Ridzwan, A. Nasiri, I. Ahmad, F. Aslani. 2014. Influence of Plant Spacing and Sowing Time on Yield of Sunflower (Helianthus annuus L.). Journal of Food, Agriculture \& Environment, 12:2, 688-691.

Bajehbaj, A.A., N. Qasimov, M. Yarina. 2009. Effects of Droughtand Potassium on Physiological and Morphological Traits of Some Cultivars of Sunflower. Journal of Food, Agriculture \& Environment, 7 (3 and 4):448- 451.

Bakht, J., S. Ahmad, M. Tariq, H. Akbar, M. Shafi. 2006. The performance of various hybrids of sunflower in Peshawar valley. J.Agri.Sci., 3: 25-29.

De la Vega, A.J., I.H. Delacy, S.C. Chapman. 2007. Progress Over 20 Years of Sunflower Breeding in Central Argentina. Field Crops Research, 100: 61-72.

Hasan, M.K., and N.O. Mukhtar. 2000. Response of Sunflower Hybrid Variety to N and P. Annual Report (2000-01). Oil Seed Crops Research Program. Wad Medani, Sudan.

Hocking, P.J., and M. Stapper. 2001. Effect of Sowing Time and Nitrogen Fertilizer on Canola and Wheat, and Nitrogen Fertilizer on Indian mustard. I. Dry Matter Production, Grain Yield, and Yield Components. Aust. J. Agric. Res., 52:623634.

Hussain, S., M.F. Saleem, J. Iqbal, M. Ibrahim, M. Ahmad, S.M. Nadeem, A. Ali, S. Atta. 2015. Abscisic Acid Mediated Biochemical Changes in Sunflower (Helianthus annuus L.) Grown under Drought and Well-Watered Field Conditions. The Journal of Animal \& Plant Sciences, 25(2): 406-416.

Kaleem, S., F.U. Hassan, M. Ahmad, I. Mahmood, A. Wasaya, M.A. Randhawa, P. Khaliq. 2011. Effect of growing degree 
days on autumn planted sunflower. African Journal of Biotechnology, 10: 8840-8846.

Karaaslan, D., Ö. Tonçer, T. Söğüt. 2007. Evaluation of In Terms of Yield and Yield Properties of Some Sunflower (Helianthus annuus L.) Cultivars in Southeastern Anatolia Region Conditions. Harran University, J. of Agric. Faculty, 11(1/2): 31-38.

Kill1, F. and S.G. Altunbay. 2005. Seed Yield, Oil Content and Yield Components of Confection and Oil Seed sunflower (Helianthus annuus L.) Cultivars Planted in Different Dates. International Journal of Agriculture and Biology, 7 (1):2124.

Krisztina, R.G., L. Erdei, S.H. Lips. 2002. The Activity of Antioxidant Enzymes in Maize and Sunflower Seedlings as Affected by Salinity and Different Nitrogen Sources. Plant Science, 162: 923-930.

Koutroubas, S.D., D.K. Papakosta. A. Doitsinis. 2008. Nitrogen Utilization Efficiency of Safflower Hybrids and OpenPollinated Varieties Under Mediterranean Conditions. Field Crops Res., 107 (1): 56-61.

Lawal, B.A., G.O. Obigbesan, W.B. Akanbi, G.O. Kolawole. 2011. Effect of Planting Time on Sunflower (Helianthus annuus L.) Productivity in Ibadan, 6 (13); 3049-3054.

Malik, M.A., R.M. Rahman, N.A.A. Cheema, M.A. Cheema. 1999. Determining a Suitable Rate and Source of Nitrogen for Realization The Higher Economic Returnes from Autumn Sown Sunflower. International Journal of Agric. and Biology, 1(4): 347-349.

Martre, L.A.P., G. Pereyra-Irujo, N. Izquierdo, V. Allard. 2009. Management and breeding strategies for the improvement of grain and oil quality. In Sadras, V. O. and Miralles, D. J. (eds). Crop Physiology. Applications for Genetic Improvement and Agronomy. Academic Press, San Diego, pp. 387-421.

Nasim, M., A. Ahmad, A. Bano, R. Olatinwo, M. Usman, T. Khaliq, A. Wajid, H. Mohkum, M.M. Hammad, M. Hussain. 2012. Effect of Nitrogen on Yield and Oil Quality of Sunflower (Helianthus annuus L.) Hybrids under Sub Humid Conditions of Pakistan. American Journal of Plant Sciences, 3: 243-251.
Olowe, V.I., O.M. Folarin, O. Adeniregun, M.O. Atayese, Y.A. Adekunle. 2013. Seed Yield, Head Characteristics and Oil Content in Sunflower Varieties as Influenced by Seeds from Single and Multiple Headed Plants Under Humid Tropical Conditions. Annals of Applied Biology, 163: 394-402.

Osama, M., A. Elhassan, A. Elnaiem, A.A.E. Mohamed, M.Y. Mohamed. 2010. Response of Sunflower to Different Types of Fertilizer and Nitrogen Levels in the Rain-Fed Area of the Blue Nile State. Agricultural Research Corporatio Unit, Wad Medani, 26-34.

Ozer, H., E. Ozturk, T. Polat. 2003. Determination of the Agronomic Performances of Some Oilseed Sunflower (Helianthus annuus L.) Hybrids Grown under Erzurum Ecological Conditions. Turkish Journal of Agriculture and Forestry, 27: 199-2005.

Petcu, E., N. Babeanu, O. Popa, E. Partal, S.M. Prico. 2010. Effect of Planting Date, Plant Population and Genotype on Oil Content a,nd Fatty Acid Composition in Sunflower. Romanian Agricultural Research, 27: 53-57.

Pritchard, F.M., H.A. Eagles, R.M. Norton, S.A. Salisbury, M. Nicolas. 2000. Environmental Effects on Seed Composition of Victorian Canola. Aust. J. Exp. Agric., 40: 679-685.

Soriano, M.A., F.J. Orgaz, F. Villalobos, E. Fereres. 2004. Efficiency of Water Use of Early Plantings of Sunflower. Europa Journal of Agronomy, 21: 465- 476.

Steel, R.G.D. and J.H. Torrie. 1980. Principles and procedures of statistics. McGaw-Hill Book Company. Inc. N.Y.

Soleymani, A., M.H. Shahrajabia, L. Naranjani. 2013. Effect of Planting Dates and Different Levels of Nitrogen on Seed Yield and Yield Components of Nuts Sunflower (Helianthus annuиs L.). African Journal of Agricultural Research, 8 (46): 5802-5805.

Toosi, A.F. and M. Azizi. 2014. Effect of Different Sources of Nitrogen Fertilizer on Yield and Yield Components of Sunflower (Helianthus annuus L.). Scientific Papers, Series A. Agronomy, LVII, 364-366.

Yassen, A.A., E.F. Abdallah, M.S. Gaballah. 2011. Response of Sunflower Plants to Nitrogen Fertilizers and Phytohormones Under Drainage Water Irrigation Australian Journal of Basic and Applied Sciences, 5 (9): 801-807. 